Ann. Biol. anim. Bioch. Biophys., 1979, 19 (2 A), 413-428.

\title{
The proteinaceous content and possible physiological significance of dense-cored vesicles in hamster and mouse pinealocytes
}

\author{
par Marie-Thérèse JUILLARD
}

\author{
Université de Poitiers, \\ Laboratoire de Zoologie et Biologie cellulaire. \\ Laboratoire associé ou CNRS n $n^{\circ} 290$ and SGMEAB \\ 40, avenue du Recteur-Pineau, 86022 Poitiers Cedex, \\ France.
}

Summary. Electron dense-cored vesicles (DCV), originating in the Golgi apparatus and migrating into the perivascular processes, constitute a characteristic feature of the pinealocytes in the pineal gland of mice and hamsters. This report presents the results of ultracytochemical studies carried out to clarify the nature and physiological significance of these vesicles. Using proteases and the PA-TCH-silver technique on ultrathin sections, it was concluded that the dense core of DCV was proteinaceous in nature. These data, correlated with previous pharmacological and cytophysiological studies, showed the important role of DCV in the storage and intracellular migration of a proteinaceous compound of unknown significance. However, in agreement with authors who hypothesized the elaboration of active peptidergic compounds in the mammalian pineal gland to explain some effects that could not be ascribed to indoleamines, it was proposed that DCV might store a carrier-neurohormone complex. The presence in the DCV of one indoleamine, such as serotonin, or of several indoleamines, has still not been established in mammals.

\section{Introduction.}

The mammalian pineal is essentially composed of two types of intrinsic cells, pinealocytes and interstitial cells (glial-like cells or astrocyte-like cells). These two types are unique due to their peculiar phylogeny. Pinealocytes are derived from photoreceptor cells and interstitial cells from the so-called supportive cells of the pineal of lower vertebrates (Collin, 1969, 1971, 1979).

A number of cytophysiological investigations have demonstrated that pinealocytes possess neuroendocrine properties, but our knowledge of their secretory processes is still in its infancy; there are fewer data on these cells than on their precursors, the rudimentary photoreceptor cells, which are intermediate between pinealocytes and photoreceptor cells in the scale of phylogenetic and ontogenetic differentiation (Collin, 1969, 1971, 1979 ; Oksche, 1971 ; Oksche et al., 1971).

One of the certain common functions of rudimentary photoreceptor cells (RP) and pinealocytes $(\mathrm{Pi})$ is the genesis of dense-cored vesicles (DCV) from the Golgi complex and their migration into the perivascular processes or the polar secretory 
terminals (Collin, 1969-1979). Most authors consider that the DCV in Pi are the storage sites of one or more active compounds. It has been concluded previously in some reptiles and birds (Collin, 1969 ; Collin and Meiniel, 1971, 1973a, b; Collin ef al., 1976, 1977a, b ; Juillard and Collin, 1976, 1978 ; Juillard ef al., 1977) that a proteinaceous compound is regularly present in the DCV and that serotonin (5-HT), probably bound to this proteinaceous compound, may be also stored in the DCV of some species and/or under certain circumstances.

This study was undertaken to clarify the ultracytochemical properties of DCV in mammalian pinealocytes since (i) it had been determined that active compounds were stored in the DCV or secretory granules of peptidergic neurons and of a number of endocrine cells engaged in the elaboration of polypeptidic or glycoproteic hormones and (ii) Quay (1974), Ebels (1976) and Benson ef al. (1976) suggested that peptidergic compounds of unknown chemical structure were present in the pineal.

This preliminary study attempts to contribute to a better understanding of the secretory processes in mammals by defining the proteinaceous content of the DCV in the pinealocytes of mice and hamsters, as observed by Collin (Pevet and Saboureau, 1973). The present data have been briefly summarized previously by Collin, Juillard and Brisson (1977b). Electron microscopic studies of the cell types studied in the present report have been carried out previously in mice (Ito and Matsushima, 1967, 1968 ; Pellegrino de Iraldi, 1969 ; Matsushima and Reiter, 1975 ; Upson et al., 1976) and hamsters (Sheridan, 1967,1969,1975; Sheridan and Reiter, 1968, 1970 ; Clabough 1971 ; Collin, 1969 ; Lin et al., 1975).

\section{Material and methods.}

Pineal localization of proteinaceous and/or glycoproteinaceous compounds have been investigated in two species of mammals : the mouse, Mus musculus, L. and the golden hamster, Mesocricetus auratus, Waterhouse. The animals were kept in normal laboratory conditions under a light/dark cycle (14 hrs. light/10 hrs. darkness)

TABLE 1

\begin{tabular}{|c|c|c|c|c|c|}
\hline $\begin{array}{c}\text { Number of } \\
\text { animals }\end{array}$ & $\begin{array}{l}\text { Time } \\
\text { killed }\end{array}$ & $\begin{array}{l}\text { Fixative : } \\
\text { glutaraldehyde } \\
\text { solution } 4^{\circ} \mathrm{C}\end{array}$ & Washing & $\begin{array}{l}\text { Postfixation } \\
4^{\circ} \mathrm{C}\end{array}$ & Embedding \\
\hline$\frac{4 \text { mice }}{3 \text { hamsters }}$ & $11: 00$ a.m. & 2,5 p. $100 ; 25 \mathrm{~min}$ & $30 \mathrm{~min}$. & $\begin{array}{c}\mathrm{OsO}_{4} \\
45 \mathrm{~min} .\end{array}$ & \multirow{3}{*}{ Epon } \\
\hline 3 mice & \multirow{2}{*}{$7: 30$ p.m. } & $\begin{array}{r}2 \text { p. } 100 ; 25 \mathrm{~min} . \\
2,5 \text { p. } 100 ; 25 \mathrm{~min} . \\
2 \text { p. } 100 ; 25 \mathrm{~min} .\end{array}$ & \multirow{2}{*}{18 hrs. } & \multirow[t]{2}{*}{$\begin{array}{c}\mathrm{OsO}_{4} 2 \mathrm{p.} 100 \\
1 \mathrm{hr} .\end{array}$} & \\
\hline 1 hamster & & 2 p. $100 ; 20 \mathrm{~min}$. & & & \\
\hline 1 mouse & \multirow[b]{2}{*}{$7: 30$ p.m. } & \multirow[b]{2}{*}{2 p. $100: 20 \mathrm{~min}}$. & \multirow[b]{2}{*}{18 hrs. } & \multirow[b]{2}{*}{ no } & \multirow[b]{2}{*}{ GMA } \\
\hline 1 hamster & & & & & \\
\hline
\end{tabular}


in a temperature-controlled room $\left(25^{\circ} \mathrm{C}\right)$. Water and standard laboratory chow were provided ad libitum. They were killed by decapitation at 11:00 a.m. and 7:30 p.m. in December and March. The pineal gland was immediately flooded with cold fixative : glutaraldehyde in $0.1 \mathrm{M}$ phosphate buffer, $\mathrm{pH} 7.4$ (table 1).

After fixation, some pineal glands were washed for $18 \mathrm{hrs}$. in phosphate buffer to eliminate the glutaraldehyde, which might inhibit proteolytic action or produce a background reaction with the PA-TCH-silver technique used.

Protein cyfochemistry. - Proteolytic extraction was performed according to Monneron (1966) and Monneron and Bernhard (1966). The ultrathin sections were collected in rings and oxidized in a 10 p. 100 periodic acid solution for 20 to $30 \mathrm{~min}$. ; after several washings they were transferred into enzymatic solutions, as shown in table 2. Two proteases were used : Pronase (Sigma Chemical Company, Saint Louis, Mo.) and Pepsin (Worthington Biochemical Corp., New Jersey).

TABLE 2

\begin{tabular}{|c|c|c|c|c|}
\hline $\begin{array}{l}\text { Number of } \\
\text { animals }\end{array}$ & Enzyme & $\begin{array}{l}\text { Concentration of } \\
\text { enzymatic solution } \\
\text { (p. 100) }\end{array}$ & Solvent & $\begin{array}{c}\text { Lenght and temperature } \\
\text { of incubation }\end{array}$ \\
\hline 8 mice & Pronase & $\begin{array}{l}0,1 \\
0,2 \\
0,3 \\
0,5\end{array}$ & $\begin{array}{c}\text { Maleate } \\
\text { buffer } \\
\text { pH } 7.4\end{array}$ & $\begin{array}{l}20 \mathrm{~min} \text {. to } 10 \mathrm{hrs} \text {. } \\
\left(40^{\circ} \mathrm{C}\right)\end{array}$ \\
\hline 5 hamsters & Pepsin & $\begin{array}{l}0,3 \\
0,4 \\
0,5\end{array}$ & $\begin{array}{c}\mathrm{HCl} \mathrm{N} / 10 \\
\mathrm{pH} 1.5\end{array}$ & $20 \min _{\left(38^{\circ} \mathrm{C}\right)} \mathrm{hrs.}$ \\
\hline
\end{tabular}

Control ultrathin sections were treated as previously, but were incubated in maleate buffer $(\mathrm{pH} \mathrm{7.4)}$ or $\mathrm{HCl} \mathrm{N} / 10(\mathrm{pH} \mathrm{1.5)} \mathrm{without} \mathrm{protease.} \mathrm{After} \mathrm{incubation} \mathrm{and}$ washings, the sections were collected for electron microscopic examination on formvar-coated copper grids stained with uranyl acetate and lead citrate.

Cytochemistry of complex carbohydrates. - We used the periodic acid-thiocarbohydrazide-silver proteinate technique (PA-TCH-silver technique). The pineal sections, mounted on golden grids, were floated $40 \mathrm{~min}$., 24,48 and $72 \mathrm{hrs}$. on thiocarbohydrazide $(\mathrm{TCH})$; they were then processed (Thiéry, 1967 ; Juillard and Collin, 1978) and examined without staining in a Hitachi Hu $11 \mathrm{Cs}$ electron microscope.

\section{Results.}

Ultrastructure and localization of dense-cored vesicles (figs. 1, 2).

A characteristic feature of the pinealocytes of both the mammals studied was the existence of clear and dense-cored vesicles (DCV) in the perikaryon, which were originating in the Golgi complex. The vesicles had a mean diameter of $110 \mathrm{~nm}$ and a 

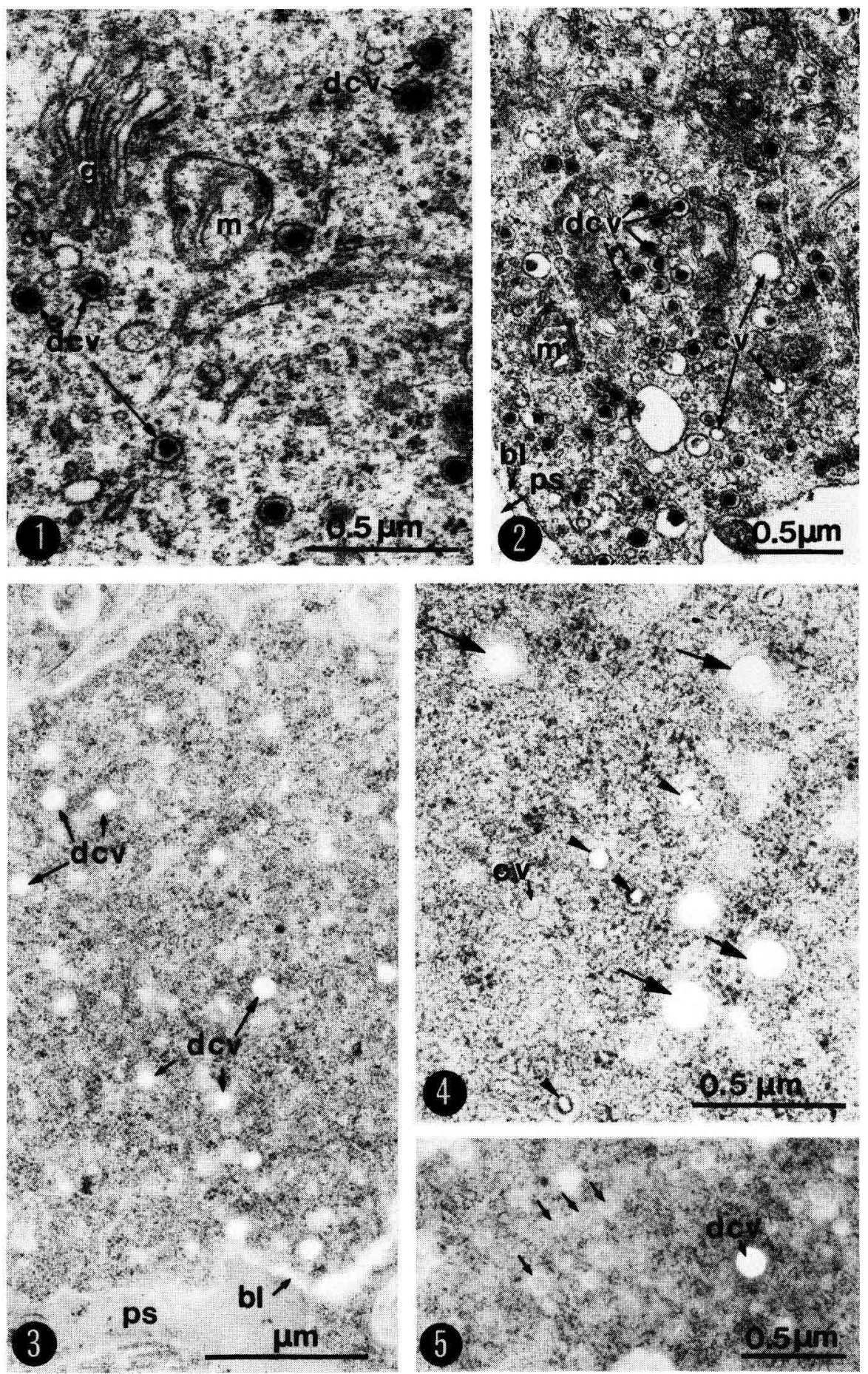
dense core of about $80 \mathrm{~nm}$ in mice (Pellegrino de Iraldi, 1969) and a diameter ranging between 65 and $170 \mathrm{~nm}$ (Collin, 1969) or from 50 to $120 \mathrm{~nm}$ (Sheridan and Reiter, 1970 ; Sheridan, 1975) in hamsters. These vesicles migrated into the perivascular terminal processes where they accumulated, at least provisionally. The electrondense core filled the DCV more or less, leaving a rim between it and the limiting membrane. The number of DCV varied in the pinealocyte endings and all intermediates between DCV with a large core and clear vesicles were observed, suggesting a release mechanism.

\section{Protein cyfochemistry.}

Control sections. - No visible changes occurred in the fine structure of nonenzymatically treated sections (compare figs. 1,2 with 7).

Enzymatically treated sections. - The same observations were made in both mammalian species :

- Pronase hydrolysis. After oxidation and 1 hr. of enzymatic treatment in 0.2 p. 100 pronase solution, the DCV dense cores were digested; they resembled clear holes (fig. 3). The collagenous fibrils, membranes and matrix of mitochondria and triplets of centrioles were also attacked. On thicker sections, a few DCV were only partly hydrolyzed, i.e. the dense core was attacked first, leaving the rim.

When a 0.1 p. 100 pronase solution was used for $1 \mathrm{hr}$, or a 0.2 p. 100 one for 30 min. (fig. 4), some DCV remained intact, but the dense core in most of them was replaced by a clear hole. Different stages of proteolysis were seen, probably depending on section thickness, the concentration of the enzymatic solution and incubation time (Monneron and Bernhard, 1966). The differences observed among DCV also depended upon the qualitative and quantitative properties of the proteinaceous compounds stored in them, perhaps due to their different stages of maturation.

On the contrary, with the enzymatic treatments used, pronase did not seem to either affect clear vesicles (fig. 5,8 ) located in the DCV population, or the microfilaments and microtubules.

FIG. 1. - Mouse pineal fixed in glutaraldehyde, embedded in epon. Normal section staining with uranyl acetate and lead citrate in the perikaryon of a pinealocyte : a Golgi complex $(\mathrm{g})$, from which clear vesicles (cv) and dense-cored vesicles (dcv) originate may be observed. $m$ : mitochondria $(\times 42000)$.

FIG. 2. - Mouse pineal fixed as previously. Normal section of a pinealocyte perivascular process, showing numerous dense-cored vesicles (dcv) and clear vesicles (cv). bl : basal lamina; $m$ : mitochondria; ps : perivascular space ( $\times 28000)$.

FIG. 3-5. - Mouse pineal. Ultrathin sections floated $30 \mathrm{~min}$. on periodic acid, then incubated in $0,2 \mathrm{p}$. 100 pronase solution. (3) during $1 \mathrm{hr}$ : dense-cored vesicles (dcv) located in a perivascular process appear like clear holes (see text). Basal lamina (bl) is also digested. ps : perivascular space ( $X$ 22 400). (4) during $30 \mathrm{~min}$ : different stages of extraction are seen in dense-cored vesicles (dcv). In some dcr the dense core is partly digested (arrowheads); in others the dense core and the rim have disappeared (arrows). cv : clear vesicle $(\times 42000)$. (5) during $30 \mathrm{~min}$ : one dense-cored vesicle (dcv) is totally digested as are membranes of clear vesicles; the content of the latter (arrows) remains intact $(\times 28000)$. 


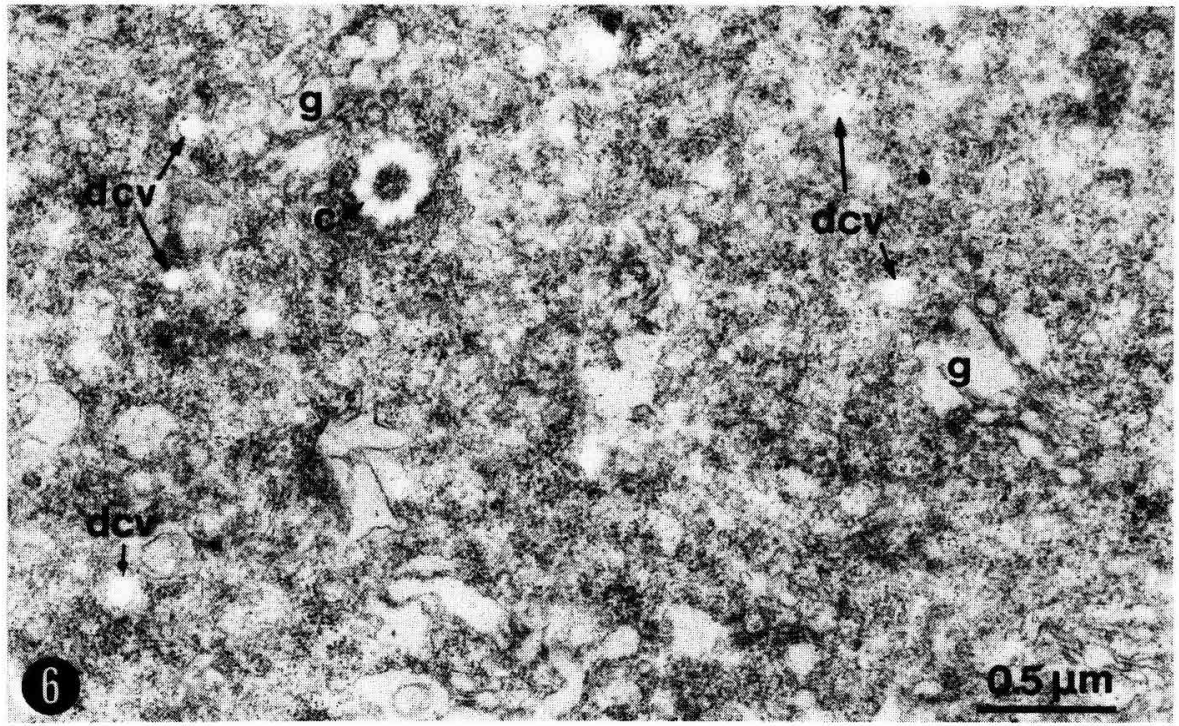

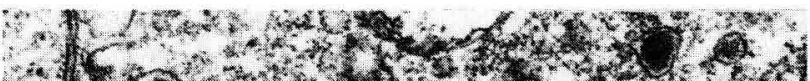

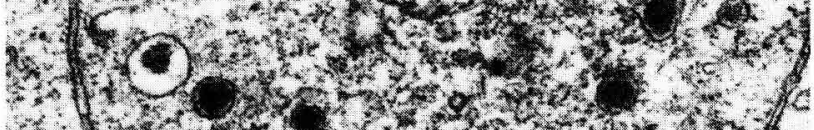

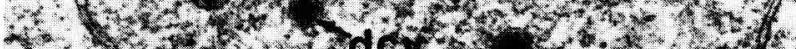

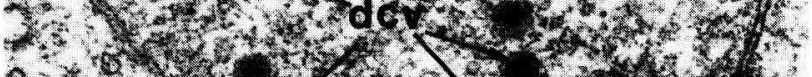

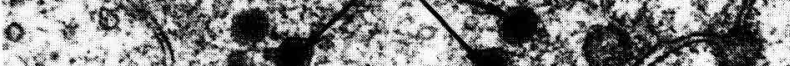

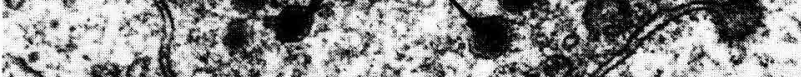

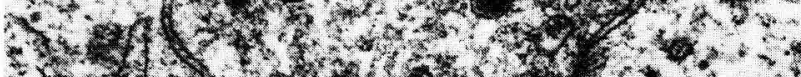

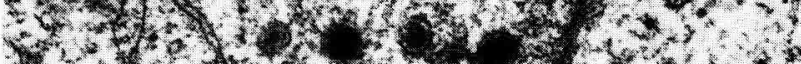

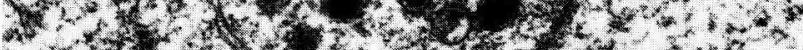

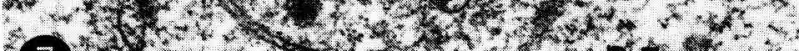

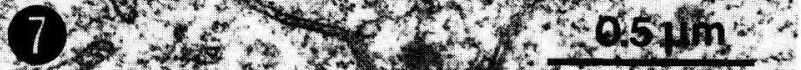

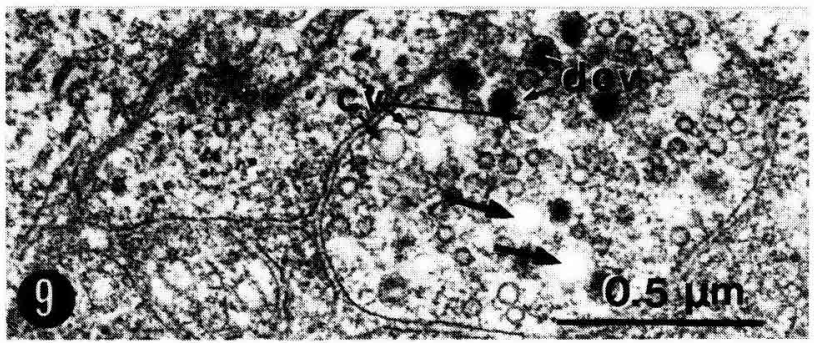

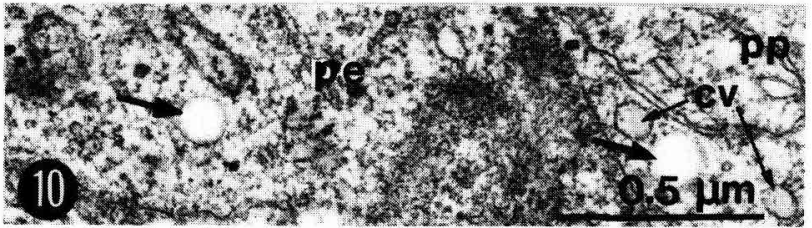

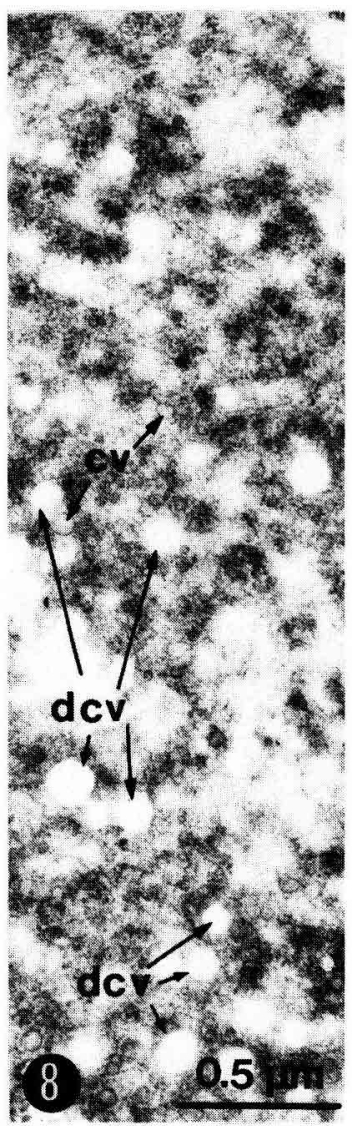


- Pepsin hydrolysis. After oxidation, pepsin action was effective with a 0.3 p. 100 enzymatic concentration. After $1 \mathrm{hr}$. of treatment, the content of some DCV completely disappeared ; other DCV were partially attacked or not. Collagenous fibrils were always quickly digested. Clear vesicles did not seem to be modified (fig. 9). When incubation time was prolonged from 2 to 9 hrs., more vesicle dense cores were digested (fig. 6, 10). Mitochondria and microtubule triplets of centrioles were also attacked, but the clear vesicles were not. When the concentration of the enzymatic solution was increased, DCV extraction was more pronounced and more DCV were digested. However, a few DCV appeared intact, indicating that their dense cores were very resistant to the proteolytic action of pepsin ; clear vesicles, microfilaments and microtubules were unmodified.

In conclusion, the dense cores of DCV were the first cell features to be attacked, after the collagenous fibrils, by both proteases, thus clearly suggesting the proteinaceous nature of the granules.

Cytochemistry of complex carbohydrates.

Control sections. When the periodic acid treatment was omitted, no silver precipitates were observed, even after $72 \mathrm{hrs}$. of exposure on $\mathrm{TCH}$ (fig. 11).

Treated sections.

A) $40 \mathrm{~min}$. of exposure on $\mathrm{TCH}$ solution demonstrated the presence of glycogen particles in most pineal cells, as evidenced by silver precipitates. The quantity varied from one cell to another. Some cells contained no glycogen. Lysosome-like bodies might also be reactive. There was a difference in the two species studied :

a) Mice : Small clusters of $\alpha$-type glycogen were generally found scattered in the cytoplasm of pinealocytes. In our material, interstitial cells were characterized by the presence of $\beta$-type glycogen particles, freely dispersed in the cytoplasma (fig. 12).

b) Hamsfers : Only clusters of a-type glycogen were found scattered in both types of pineal cells.

FIG. 6. - Mouse pineal. Section in the pinealocyte perikaryon, oxidized by periodic acid, then floated for 4 hrs on 0.3 p. 100 pepsin. The dense cores of dense-cored vesicles (dcv), originating in Golgi complex (g), and triplets of a centriole (c) are completely extracted ( $\times 28000)$.

FIG. 7-10. - Hamster pineal. (7) Control section, oxidized by periodic acid then floated on $\mathrm{HCIN} / 10$ free of protease : in the pinealocyte process the dense-cored vesicles (dvc) are intact $(\times 42000)$. (8) Section oxidized then floated $30 \mathrm{~min}$. on $0.4 \mathrm{p} .100$ pronase in maleate buffer. The dense-cored vesicles (dcv) are totally digested. The content of clear vesicles is persistent $(\times 33600)$. (9) Section treated on $0.3 \mathrm{p} .100$ pepsin for $1 \mathrm{hr} 30$. Some dense-cored vesicles (dcv) are intact while the dense cores of others (arrowheads) are totally digested. Clear vesicles (cv) are not modified $(\times 42000)$. (10) Section treated as in fig. 6. The dense cores of dense-cored vesicles, located in a pinealocyte process (PP) and in a pinealocyte perikaryon (pe), are totally digested. A thin rim (arrow) is present. The content of clear vesicles (cv) seem to be unattacked by pepsin ( $X 42000$ ). 


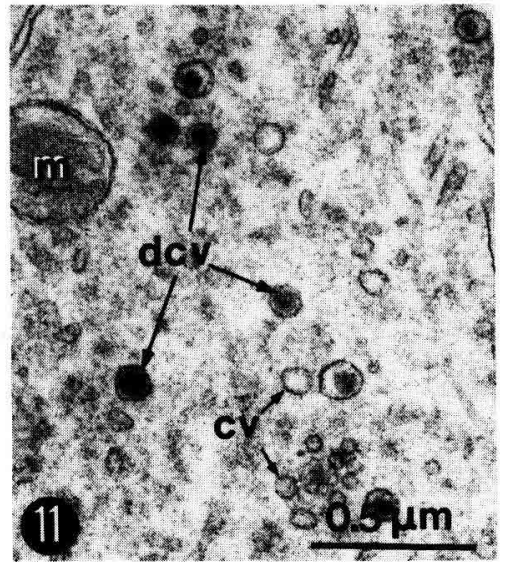

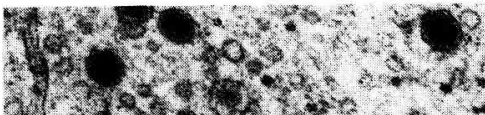

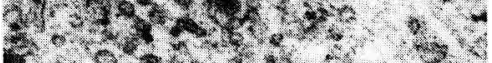

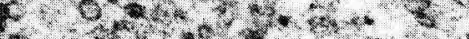

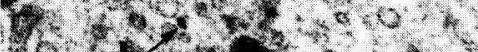

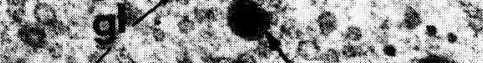

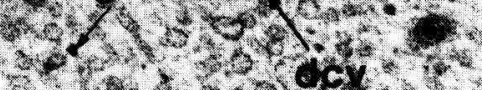

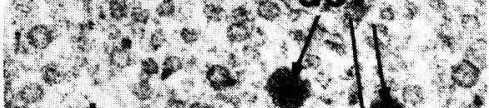

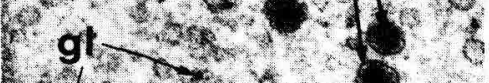

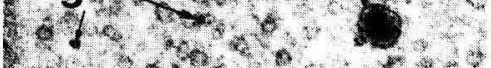

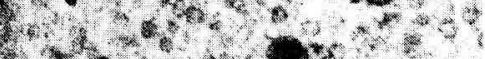
$13 x^{2}: 2^{*}+30.5 \mu \mathrm{m}^{2}$

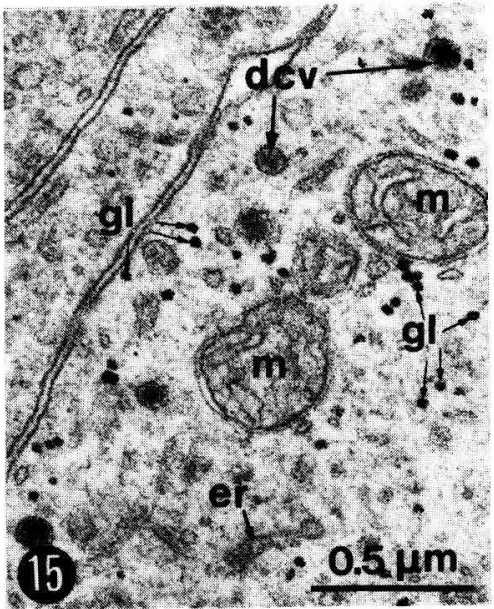

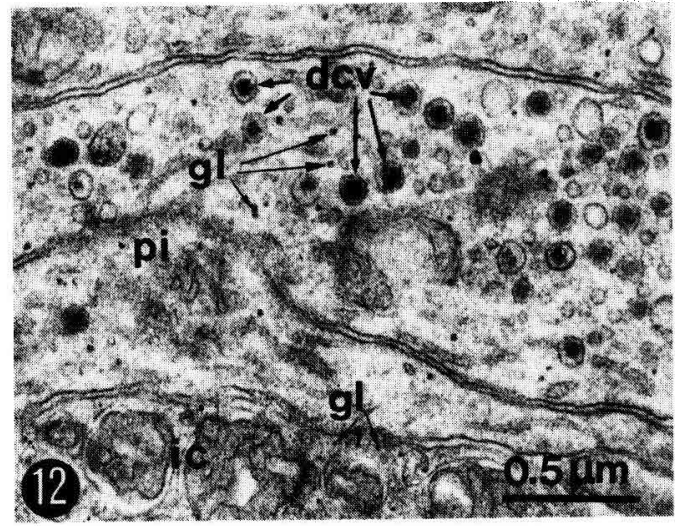
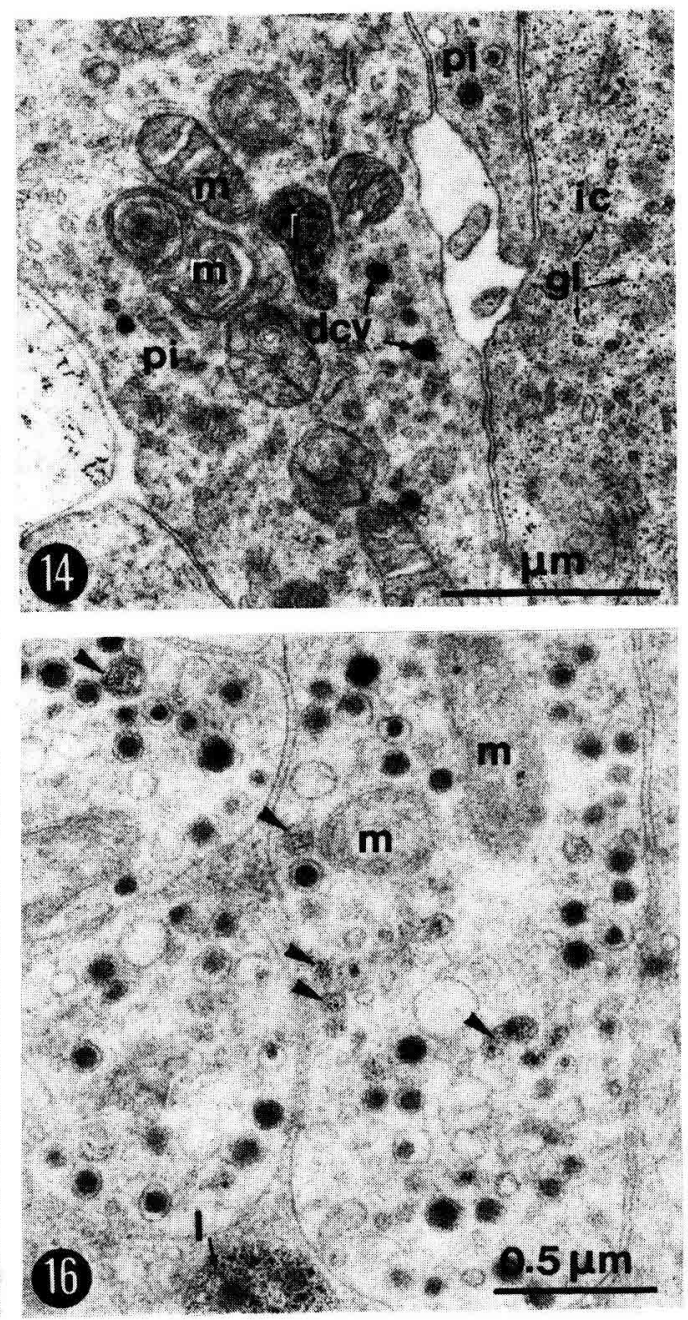
B) After 24 or $48 \mathrm{hrs}$. of TCH treatment (revealing mucopolysaccharides, figs. 13, 14), or after 72 hrs. (indicating the presence of glycoproteins, figs. 15, 16), the ultrathin sections were not very different from those observed previously, except that positive reactions occurred in some clear vesicles, mostly localized in the pinealocyte regions containing dense-cored vesicles. The core and the rim of the DCV were never labelled by silver precipitates, whatever the length of incubation. Glycoproteins were not observed (see Discussion) in our conditions.

\section{Discussion.}

\section{Pinealocyte secrefory processes.}

In studies on laboratory rats or wild mammals, Pevet (1977a), Pevet and Karasek (1977), Karasek and Marek (1978) considered two types of secretory processes in pinealocytes. One was first proposed by Vivien (1964) in the ringed-snake, then generalized to other Amniota by Collin $(1969,1971,1976,1979)$ and Oksche et al. (1971) ; it was characterized by the formation of dense-cored vesicles (DCV) in the Golgi complex ; the other type was recently proposed by Pevet and Karasek and corresponds to the elaboration of material directly from the cisternae of the rough endoplasmic reticulum. Pevet (1977b) studying moles, demonstrated the proteinaceous nature only of the material present in cisternae.

On the basis of ultracytochemical, cytophysiological and biochemical data, Collin (1969-1979) distinguished the elaboration of proteinaceous compounds-struc-

FIG. 11. - Mouse pineal. Pinealocyte control section treated according to PA-TCH-silver technique except periodic acid treatment. After 72 hrs on thiocarbohydrazide, no silver precipitate is observed. $\mathrm{cv}$ : clear vesicle ; dcr : dense-cored vesicles ; $\mathrm{m}$ : mitochondria ( $\times 33600)$.

FIG. 12. - Mouse pineal. Section treated according to PA-TCH-silver technique. After $40 \mathrm{~min}$. of thiocarbohydrazide treatment, the silver precipitates indicate the presence of glycogen ( $\mathrm{gl}$ ) particles in pinealocytes (pi) and interstitial cell (ic) processes. dcv : dense-cored vesicles $(\times 28000)$.

FIG. 13. - Hamster pineal. Section stained according to PA-TCH-silver technique, with 24 hrs on thiocarbohydrazide. Electron dense particles of glycogen ( $\mathrm{gl}$ ) are scattered in cytoplasm. No reaction on dense-cored vesicles $(\mathrm{dcv})(\times 42000)$.

FIG. 14. - Mouse pineal. Section stained as previously. Very fine, highly electron-dense $\beta$-particles of $\mathrm{glycogen}(\mathrm{gl})$ are scattered in the hyaloplasm of an interstitial cell (ic). In two pinealocytes (pi), no glycogen particles are defected in the hyaloplasm. The dense-cored vesicles (dev) are not reactive. Only a lysosomal-like body $(I)$ is filled with silver precipitates. $m$ : mitochondria ( $X$ 22 400).

FIG. 15. - Mouse pineal. Section stained as previously but treated on thiocarbohydrazide during 72 hrs. Numerous clusters of $\alpha$-particles of glycogen ( $\mathrm{gl}$ ) are observed in the pinealocyte hyaloplasm. The dense-cored vesicles (dcv) are not reactive. er : endoplasmic reticulum ; $m$ : mitochondria $(\times 33600)$.

FIG. 16. - Mouse pineal. Section stained as previously. In these pinealocyte processes, precipitates are absent in hyaloplasm. Only some scarce clear vesicles are filled with electron-dense parficles (arrowheads). 1 : reactive lysosomal-like body ; $m$ : mitochondria ( $\times 33600$ ). 
fural proteins, enzymes, neurohormone (?) - from that of indoleamines in the same cell type (pinealocytes or rudimentary photoreceptor cells). The usual sequence of events in the protein secretion of rudimentary photoreceptor cells (RP) and pinealocytes ( $\mathrm{Pi}$ ) was compared to that of peptidergic neurons : synthesis by a ribosomal mechanism (ribosomes attached to the rough endoplasmic reticulum membrane), segregation and intracellular transport into the endoplasmic reticulum, concentration in the Golgi complex, intracellular storage and migration of some proteins (a peptidergic neurohormone ?) into the DCV, and release. However, the mechanisms of release of DCV content by diffusion and/or exocytosis were not definitively established, and whether the production of DCV and that of material originating directly from the cisternae of the rough endoplasmic reticulum « are in some way coupled or indeed function independently remains to be elucidated » (Pevet and Karasek, 1977 ; Karasek and Marek, 1978). However, it must also be noted that the material originating directly from the cisternae of the rough endoplasmic reticulum is not specific to pinealocytes, the chief cells of the pineal gland (Collin, 1979). According to Collin (1979), such a phenomenon was observed in the interstitial (supportive) cells of several lower vertebrates and mammals, i.e. the so-called pinealocytes of population II (Pevet, 1977a) and more recently in the receptor cells of pike (Falcon, unpublished data).

The other secretory process (Collin, 1979) present in RP, as in $\mathrm{Pi}$, concerns the elaboration of indoleamines and is quite different from that of protein secretion. This second process, apparently absent in peptidergic neurons, is well known in the endocrine cells of the APUD series (Pearse, 1969). In the biosynthesis of indoleamines « an enzymatic process replaces the ribosomal mechanism. In this case, a transport mechanism would be also involved, because biosynthetic enzymes have to be transported from their sites of formation to their sites of activity » (Collin, 1979). These sites of activity were also analyzed by the same author.

\section{Uliracyfochemical properties of DCV.}

In this report, the presence of a proteinaceous compound in the pinealocyte DCV of two mammals is determined, using two proteolytic enzymes, pronase and pepsin. The action mechanisms of these proteases have been extensively discussed (Monneron, 1966 ; Monneron and Bernhard, 1966 ; Collin and Meiniel, 1972 ; Juillard and Collin, 1978). The data of the present ultracytochemical study using proteases, and that of previous studies in our laboratory, confirm the results of some physiologists and biochemists showing that the mammalian pineal produces active low molecular weight compounds (peptides or polypeptides), mainly studied in terms of their reproductive effects. Pi, as well as RP, are protein-secreting cells.

The absence of positive reactions after the use of the PA-TCH-silver technique (Thiéry, 1967) does not negate the presence of glycoproteins in DCV; Krstic (1975, 1976, and personal communication to Collin) found them in the DCV of rats. The apparent contradiction in DCV glycoprotein content in different rodents may be provisionally explained by a possible circadian rhythm of this substance, similar to the rhythm of glycogen in mice (Kachi ef al., 1971 a, b, 1975). Furthermore, in the present work, glycogen has been localized in mice and hamsters, although only in special conditions (see Material and methods). 
Since methoxyindoles (melatonin and methoxytryptophol) have been considered as active compounds of the mammalian pineal (Minneman and Wurtman, 1975), several authors have suggested the presence of such substances (or that of the precursor, 5-HT) in DCV. Some monoamines were found in association with a proteinaceous compound in the DCV or secretory granules of monoaminergic neurons or of APUD cells. The supposition that one or more indoleamines might be present in pinealocyte DCV incited a number of pharmacological investigations ; several drugs believed to change indoleamine storage and metabolism were used mainly in vivo (Collin, 1979). For example, in hamsters, mice, rats and rabbits (Pellegrino de Iraldi, 1966, 1969 ; Arstila, 1967 ; Romijn, 1976), the DCV were not depleted by reserpine. When Romijn $(1972,1976)$ used P-CPA, an inhibitor of the biosynthesis of 5-HT and p-chloroamphetamine lowering the activity of tryptophan-5-mono-oxygenase, no apparent changes were observed in the DCV of rabbits. Similar results were obtained recently using complementary techniques in a very complete study of the parakeet (Collin et al., 1976 ; Juillard et al., 1977 ; Juillard and Collin, 1978). In Amniota, variations observed after drug treatments mainly concern the number and the diameter of DCV. These results are difficult to interpret (Collin, 1979) owing to present insufficient knowledge of the chemical structure of DCV and to the fact that it is impossible to dissociate the well known role of the drugs from their less specific action (von Euler, 1973). Thus, since electron microscopic studies of the DCV dense core in Amniota showed hardly any or no qualitative modification (as contrasted with the granulated vesicles of pineal sympathetic endings under reserpine treatment), Collin (1979) suggested that indoleamines, when present in DCV, could not be directly visualized on the classical ultrathin sections because they were masked by another proteinaceous compound, as shown previously by Collin and Meiniel (1972), Petit (1976), VivienRoels (1976) studying reptiles, Juillard and Collin (1978) studying birds and Juillard studying mammals here (Collin et al., 1977 a).

Apparently only one preliminary observation in the literature concerns the presence of 5-HT in the DCV of hamster pinealocytes (Lin et al., 1975). New studies must be carried out in this direction.

However, considering the variations of 5-HT content - as shown by the technique of Falck et al. (1962) in mammals and in other groups of vertebrates (Collin, 1979) and the pharmacological data, it is definitively demonstrated that a proteinaceous compound is regularly present in the DCV of RP cells and $\mathrm{Pi}$. The presence of $5-\mathrm{HT}$ in DCV varies in different species, depending upon the quantity of remaining $5-\mathrm{HT}$ (which is not rapidly metabolized) and probably also, in a given species, upon daily changes ; the circadian rhythm of $5-\mathrm{HT}$ and its related indoleamines is well known (Quay, 1974 ; Wurtman et al., 1968 ; Axelrod, 1974, 1977 ; Axelrod and Zatz, 1977). Furthermore, many other sites in pinealocytes, interstitial cells and sympathetic fibers could store 5-HT (Collin, 1979).

\section{Physiological significance of DCV proteinaceous content.}

From the many experiments on mammals, it appears that pinealocyles are very sensitive cells and that several kinds of inputs control their secretory processes (Collin, 1979). From a cytophysiological point of view, a number of pinealocyte organelles, 
including DCV, have been experimentally modified qualitatively and/or quantitatively. DCV decrease or increase was obtained in a seasonal breeder (Roux ef al., 1977) and after blinding and continuous darkness in hamsters (Sheridan, 1975) and mice (Upson and Benson, 1977) ; continuous illumination in mice (Upson et al., 1976); sympathectomy in rabbits (Romijn, 1975), hamsters (Lin ef al., 1975 ; Sheridan, 1975) and mice (Pellegrino de Iraldi, 1969); administration of parasympatholytic drugs in rabbits (Romijn, 1976) ; surgical castration in rats (Karasek ef al., 1976) ; injection of human chorionic gonadotropin (HCG) and pregnant mare serum gonadotropin (PMSG) in rats (Karasek and Marek, 1978); in the presence of norepinephrine (NE) or dibutyryl-cyclic-adenosine 3'-5'-monophosphate (db-c-AMP) in rat pineals cultured in vitro (Karasek, 1974) or in rabbits (Romijn and Gelsema, 1976). It has also been shown that a mean number of DCV in rabbits (Romijn et al., 1976) and mice (Benson and Krasovich, 1977) have a circadian rhythm. From experiments with melatonin administration or with sympathectomy, Benson and Krasovich (1977) concluded that DCV rhythms depended upon intact innervation.

All these quantitative variations of DCV, as the qualitative and quantitative variations of other organelles implied in the process of protein secretion (Collin, 1979), suggest (as in peptidergic neurons and some endocrine cells) that DCV may play an important role in the mechanisms of storage, intracellular transport and release of an active proteinic compourd. The cytophysiological and ultracytochemical data of this study agree with those of authors who, from biochemical and physiological data, have suggested the presence of specific peptide or protein hormones in mammalian pineals (Quay, 1974 ; Ebels, 1976 ; Benson ef al., 1976).

Upson ef al. (1976), and Benson and Krasovich (1977) in particular, proposed that DCV might contain an antigonadotropic principle. Naturally, if new experiments are necessary to check or to discard this hypothesis, it is also to be supposed - on the basis of the various effects of the pineal (Wurtman et al., 1968 ; Quay, 1974 ; Relkin, 1976) - that the presumed active protein principle, stored in DCV, plays a more general role, possibly acting on gonadic target cells (via the hypothalamus), but indirectly or directly on other target cells.

Finally, taking into account the detailed discussions of previous papers on reptiles, birds and mammals (Collin and Meiniel, 1971 ; Collin, 1976, 1979 ; Collin et al., $1977 a, b$; Juillard and Collin, 1978), this report suggests that the usual proteinaceous component of DCV may be :

1) a carrier for serotonin and perhaps some derivatives, but that it is probably

2) a specific complex peptidergic neurohormone-carrier to which a more or less important part of the indoleaminergic pool may be bound. Such a peptidergic neurohormone would contribute to explain the pineal effects that cannot be ascribed to active indoleamines.

Reçu en juillet 1978

Accepté en octobre 1978

Acknowledgements. - The author wishes to thank Prof. J. P. Collin for helpful advice. She is also grateful to D. Decourt for typing the manuscript and to G. Baudu and F. Chevalier for photographic assistance. 
Résumé. Les pinéalocytes de la Souris et du Hamster sont caractérisés par la présence de vésicules à cœur dense d'origine golgienne, qui émigrent dans les prolongements à polarité vasculaire.

De l'étude ultracytochimique, mettant à profit l'action de protéases et la technique à l'acide périodique-thiocarbohydrazide-protéinate d'argent, il ressort que le cœur dense des vésicules est de nature protéique.

Ces résultats, de même que les études pharmacologiques et cytophysiologiques antérieures, soulignent le rôle important que peuvent jouer les vésicules à cœur dense dans le stockage et la migration intracellulaire d'un composé protéique dont la signification est encore inconnue. Compte tenu de l'existence de principes actifs de nature vraisemblablement peptidique dans la pinéale des Mammifères, on suggère que les vésicules à cœur dense pourraient stocker un complexe protéique vecteur-neurohormone.

\section{References}

ARSTILA A. U., 1967. Electron microscopic studies on the structure and histochemistry of the pineal gland of the rat. Neuroendocrinology, Suppl., 2, 1-101.

AXELROD J., 1974. The pineal gland : a neurochemical transducer. Science, 184, 1341-1348.

AXELROD J., 1977. Regulation of the synthesis release and actions of catecholamine neurotransmitters, 137-155. In DUMONT J., and NUNEZ J., Hormones and cell regulation. Biomed. Press, Elsevier, North-Holland.

AXELROD J., ZATZ M., 1977. The $\beta$-adrenergic receptor and the regulation of circadian rhythms in the pineal gland, 249-268. In LITWACK G., Biochemical actions of hormones, Vol. 4, Acad. Press, New-York, London.

BENSON B., KRASOVICH M., 1977. Circadian rhythm in the number of granulated vesicles in the pinealocytes of mice. Effects of sympathectomy and melatonin treatment. Cell Tiss. Res., 184, 499-506.

BENSON B., MATTHEWS M. J., HRUBY V. J., 1976. Characterization and effects of a bovine pineal antigonadotropic peptide. Amer. Zool., 16, 17-24.

CLABOUGH J. W., 1971. Ultrastructural features of the pineal gland in normal and light deprived golden hamsters. Z. Zellforsch., 114, 151-164.

COLLIN J. P., 1969. Contribution à l'étude de l'organe pinéal. De l'épiphyse sensorielle à la glande pinéale : modalités de transformation et implications fonctionnelles. Ann. Stat. Biol. Besse-enChandesse, Suppl. 1, 1-359.

COLLIN J.P., 1971. Differentiation and regression of the cells of the sensory line in the epiphysis cerebri, 79-125. In WOLSTENHOLME G. E. W., KNIGHT J., The pineal gland, Churchill Livingstone, Edinburg-London.

COLLIN J. P., 1977. La rudimentation des photorécepteurs dans l'organe pinéal des Vertébrés, 393-407. In Méconismes de la rudimenfation des organes chez les embryons de Vertébrés. Coll. int. CNRS, $n^{\circ} 266$, Paris.

COLLIN J. P., 1979. The pineal organ of vertebrates. Ultrastructure, cytochemistry and functional evolution of the chief cells. In BOURNE G. H., DANIELLI J. F., International review of cytology, Acad. Press, New-York, London (in press).

COLLIN J. P., CALAS A., JUILLARD M. T., 1976. The avian pineal organ. Distribution of exogenous indoleamines : a qualitative study of the rudimentary photoreceptor cells by electron microscopic radioautography. Exp. Brain Res., 25, 15-33.

COLLIN J. P., JUILLARD M. T., BRISSON P., 1977a. Ultracytochemistry and pharmacology of the specific secretory granules (SG) in the pineal organ of some reptiles, birds and mammals. Intern. Symp. on "The pineal gland ", Jerusalem, abstr. no 22, 27.

COLLIN J. P., JUILLARD M. T., FALCON J., 1977b. Localization of 5-hydroxytryptamine and protein(s) in the secretion granules of the rudimentary photoreceptor cells in the pineal of Lacerfa. J. Neurocytol., 6, 541-554. 
COLLIN J. P., MEINIEL A., 1971. L'organe pinéal. Etudes combinées ultrastructurales, cytochimiques (monoamines) et expérimentales chez Testudo mauritanica. Grains denses des cellules de la lignée « sensorielle " chez les Vertébrés. Arch. Anat. micr. Morph. Exper., 60, 269-304.

COLLIN J. P., MEINIEL A., 1972. L'organe pinéal du genre Lacerta (Reptile, Lacertilien) : action d'enzymes protéolytiques sur les grains denses (500-3 400 $\AA$ ) des photorécepteurs rudimentaires. C. R. Soc. Biol., 166, 370-374.

COLLIN J. P., MEINIEL A., 1973a. Métabolisme des indolamines dans l'organe pinéal de Lacerfo (Reptiles, Lacertiliens). I. Intégration sélective de $5-\mathrm{HTP}^{3} \mathrm{H}$ (5-hydroxy-tryptophane- ${ }^{3} \mathrm{H}$ ) et rétention de ses dérivés dans les photorécepteurs rudimentaires sécrétoires. $Z$. Zellforsch., 142, 549-570.

COLLIN J. P., MEINIEL A., 1973b. Métabolisme des indolamines dans l'organe pinéal de Laceria (Reptiles, Lacertiliens). II. L'activité MAO ef l'incorporation de $5-\mathrm{HTP}-{ }^{3} \mathrm{H}$ ef de $5-\mathrm{HT}_{-}{ }^{3} \mathrm{H}$, dans les conditions normales et expérimentales. Z. Zellforsch., 145, 331-361.

EBELS I., 1976. Isolation of avian and mammalian pineal indoles and antigonadotropic factors. Amer. Zool., 16, 5-15.

EULER U. S. Von, 1973. Drugs affecting the adrenergic transmitter release and uplake, 251-278. In DIKSTEIN S., Fundamentals of cell pharmacology, Charles C. Thomas, Springfield.

FALCK B., HILLARP N. A., THIEME G., TORP A., 1962. Fluorescence of catecholamines and related compounds condensed with formaldehyde. J. Histochem. Cytochem., 10, 348-354.

ITO T., MATSUSHIMA S., 1967. A quantitative morphological study of the postnatal development of the pineal body of the mouse. Anat. Rec., 159, 447-452.

ITO T., MATSUSHIMA S., 1968. Electron microscopic observations on the mouse pineal with particular emphasis on its secretory nature. Arch. histol. jap., 30, 1-15.

JUILLARD M. T., COLLIN J. P., 1976. L'organe pinéal aviaire : étude ultracyfochimique et pharmacologique d'un " pool » granulaire de 5-hydroxytryptamine chez la perruche (Melopsitfacus undulotus, Shaw). J. Microsc. Biol. cell., 26, 133-138.

JUILLARD M. T., COLLIN J. P., 1978. The avian pineal organ : evidence for a proteinaceous component in the secretion granules of the rudimentary photoreceptor cells. An ultracytochemical and pharmacological study in the parakeet. Biol. cell., 31, 51-58.

JUILLARD M. T., HARTWIG H. G., COLLIN J. P., 1977. The avian pineal organ. Distribution of endogenous monoamines; a fluorescence microscopic, microspectrofluorimetric and pharmacological study in the parakeet. J. neural Transm., 40, 269-287.

KACHI T., MATSUSHIMA S., ITO T., 1971a. Effects of continuous lighting on glycogen in the pineal cells of the mouse : a quantitative histochemical study. Z. Zellforsch., 118, 214-220.

KACHI T., MATSUSHIMA S., ITO T., 1971b. Diurnal changes in glycogen content in the pineal cells of the male mouse. Z. Zellforsch., 118, 310-314.

KACHI T., MATSUSHIMA S., ITO T., 1975. Postnatal observations on the diurnal rhythm and the light - responsiveness in the pineal glycogen content in mice. Anat. Rec., 183, 39-46.

KARASEK M., 1974. Ultrastructure of rat pineal gland in organ culture : influence of norepinephrine, dibutyryl cyclic adenosine 3', 5'-monophosphate and adenohypophysis. Endokrinologie, 64, 106-114.

KARASEK M., MAREK K., 1978. Influence of gonadotropic hormones on the ultrastructure of rat pinealocytes. Cell Tiss. Res., 188, 133-141.

KARASEK M., PAWLIKOWSKI M., ARIENS KAPPERS J., STEPIEN H., 1976. Influence of castration followed by administration of LH-RH on the ultrastructure of rat pinealocytes. Cell Tiss. Res., 167, 325-339.

KRSTIC R., 1975. Perjodatreaktive Stellen in den Zellen der Glandula pinealis der Ratte. Acta anat. (Basel), 93, 316.

KRSTIC R., 1976. Ultracytochemistry on the synaptic ribbons in the rat pineal organ. Cell Tiss. Res., 166, 135-143.

LIN H. S., HWANG B. H., TSENG C. Y., 1975. Fine structural changes in the hamster pineal gland after blinding and superior cervical ganglionectomy. Cell Tiss. Res., 158, 285-299.

MATSUSHIMA S., REITER R. J., 1975. Ultrastructural observations of pineal gland capillaries in four rodent species. Am. J. Anat., 143, 265-282.

MINNEMAN K. P., WURTMAN R. J., 1975. Effects of pineal compounds on mammals. Life Sci., 17, 1189-1200. 
MONNERON A., 1966. Utilisation de la pronase en cytochimie ultrastructurale. J. Microscopie, 5, 583-596.

MONNERON A., BERNHARD W., 1966. Action de certaines enzymes sur des tissus inclus en épon. J. Microscopie, 5, 697-714.

OKSCHE A., 1971. Sensory and glandular elements of the pineal organ, 127-146. In WOLSTENHOLME G. E. W., KNIGHT J., The pineal gland, Churchill Livingstone, EdinburghLondon.

OKSCHE A., UECK M., RÜDEBERG, C., 1971. Comparative ultrastructural studies of sensory and secretory elements in pineal organs. Mem. Soc. Endocrinol., 19, 7-25.

PEARSE A. G. E., 1969. The cytochemistry and ultrastructure of polypeptide hormone-producing cells of the APUD series, and the embryologic, physiologic and pathologic implications of the concept. J. Histochem. Cytochem., 17, 303-313.

PELLEGRINO de IRALDI A., 1966. Granular vesicles in the pinealocytes of the hamster. Anat. Rec., 154, 481.

PELLEGRINO de IRALDI A., 1969. Granulated vesicles in the pineal gland of the mouse Z. Zellforsch., $101,408-418$.

PETIT A., 1976. Contribufion à l'éfude de l'épiphyse des Reptiles : le complexe épiphysaire des Lacertiliens ef l'épiphyse des Ophidiens. Etude embryologique, structurale, ultrasiructurale ; analyse qualitative ef quantitative de la sérotonine dans des conditions normales ef expérimentales. Thèse Doct. Sci., no 997, Strasbourg, 205 p.

PEVET P., 1977a. On the presence of different populations of pinealocytes in the mammalian pineal gland. J. neural Transm., 40, 289-304.

PEVET P., 1977b. The pineal gland of the mole (Talpa europoea L.). IV. Effect of pronase on material present in cisternae of the granular endoplasmic reticulum of pinealocytes. Cell Tiss. Res., 182, 215-219.

PEVET P., KARASEK M., 1977. Are the pineal active compounds of mammals proteinaceous in nature? An ultrastructural confribution. Acta med. pol., 18, 351-353.

PEVET P., SABOUREAU M., 1973. L'épiphyse du Hérisson (Erinaceus europaeus L.) mâle. I. Les pinéalocytes et leurs variations ultrastructurales considérées au cours du cycle sexuel. Z. Zellforsch., 143, 367-385.

QUAY W. B., 1974. Pineal chemistry. Charles C. Thomas, Springfield, 430 pp.

RELKIN R., 1976. The pineal gland, D. F. Horrobin, Eden Press, Montreal, 187 pp.

ROMIJN H. J., 1972. Strucfure and innervation of the pineal gland of the rabbit, Oryctolagus cuniculus (L.), with some functional considerations. Thesis, Amsterdam. 79 pp.

ROMIJN H. J., 1975. The ultrastructure of the rabbit pineal gland after sympathectomy, parasympathectomy, continuous illumination and continuous darkness. J. Neural Transm., 36, 183-194.

ROMIJN H. J., 1976. The influence of some sympatholytic, parasympatholytic and serotonin-synthesis-inhibiting agents on the ultrastructure of the rabbit pineal organ. Cell Tiss. Res., 167, 167-177.

ROMIJN H. J., GELSEMA A. J., 1976. Electron microscopy of the rabbit pineal organ in vitro. Evidence of norepinephrine-stimulated secretory activity of the Golgi apparatus. Cell Tiss. Res., 172, 365-377.

ROMJIN H. J., MUD M. T., WOLTERS P. S., 1976. Diurnal variations in number of Golgi-dense core vesicles in light pinealocytes of the rabbit. J. neural Transm., 38, 231-237.

ROUX M., RICHOUX J. P., CORDONNIER J. L., 1977. Influence de la photopériode sur l'ultrastructure de l'épiphyse avant et pendant la phase génitale saisonnière chez la femelle du lérot (Eliomys quercinus). J. Neural Transm., 41, 209-223.

SHERIDAN M. N., 1967. Fine structure of the hamster pineal gland. Anat. Rec., 157, 320.

SHERIDAN M. N., 1969. Further observations of the fine structure of the hamster pineal gland. Anat. Rec., 163, 262.

SHERIDAN M. N., 1975. Pineal gland fine structure, 324-336. In KNIGGE K. M., SCOTT D. E., KOBAYASHI H., ISHII S., Brain endocrine inferaction. II. S. Karger, Basel, Switzerland.

SHERIDAN M. N., REITER R. J., 1968. The fine structure of the hamster pineal gland. Am. J. Anat., 122, 357-376.

SHERIDAN M. N., REITER R. J., 1970. Observations on the pineal system in the hamster. II. Fine structure of the deep pineal. J. Morph., 131, 163-178. 
THIERY J. P., 1967. Mise en évidence des polysaccharides sur coupes fines en microscopie électronique. J. Microscopie, 6, 987-1018.

UPSON R. H., BENSON B., 1977. Effects of blinding on the ultrastructure of mouse pinealocytes with particular emphasis on the dense-cored vesicles. Cell Tiss. Res., 183, 491 498.

UPSON R. H., BENSON B., SATTERFIELD V., 1976. Quantitation of ultrastructural changes in the mouse pineal in response to continuous illumination. Anat. Rec., 184, 311-324.

VIVIEN J. H., 1964. Ultrastructure des constituants de l'Epiphyse de Tropidonotus natrix L., C. R. Acad. Sci., Paris, 258, 3370-3372.

VIVIEN-ROELS B., 1976. L'épiphyse des Chéloniens. Efude embryologique, strucfurale, ultrastructurale ; analyse qualitative et quantitative de la sérotonine dans des conditions normales ef expérimentales. Thèse Doc. Sci., no 990, Strasbourg, 188 p.

WURTMAN R. J., AXELROD J., KELLY D. E., 1968. The pineal. Acad. Press, New-York. 